\title{
THE CHURCH'S ATTITUDE TO THE MEANS AND PHILOSOPHY OF COMMUNICATION IN THE 9TH AND 16TH CENTURIES: COURAGE AND TRUST VERSUS ESCAPE AND CENSORSHIP
}

\author{
Andrzej Adamski - Barbara Przywara - Sylwia Przybyło
}

DOI: 10.17846/CL.2020.13.2.111-123

\begin{abstract}
ADAMSKI, Andrzej - PRZYWARA, Barbara - PRZYBYŁO, Sylwia. The Church's Attitude to the Means and Philosophy of Communication in the 9th and 16th Centuries: Courage and Trust Versus Escape and Censorship. This article is interdisciplinary. It concerns the research area of communication and media studies, theology and history. The authors analyze papal documents issued in the sixteenth and seventeenth centuries, which concerned the distribution of the so-called avvisi - handwritten ephemeral writings, commonly regarded as prototypes of modern press. The authors put forward the hypothesis that the criticism of avvisi at that time was mainly based on an immediate political need, while arguments of theological nature had less influence on this attitude. Nevertheless, such an attitude should be regarded as conservative and withdrawing. The authors juxtapose it with a diametrically different approach to the issue of communication, which the Church presented in relation to the mission of Cyril and Methodius. The courageous and trusting attitude of inculturation and treating the language of the Slavic peoples as an instrument of evangelization allowed for more effective missionary activities.
\end{abstract}

Keywords: social communication and journalism, avvisi, the Catholic Church, Constantine and Methodius

\section{Introduction}

During the SARC-CoV-2 coronavirus pandemic in March 2020, the Holy See and individual bishops gave the faithful dispensations from the obligation to participate in the Sunday Eucharist, recommending spiritual communication with the Church community through radio, television or Internet transmissions. This form of participation in an emergency such as a pandemic was considered fully-fledged and had the same spiritual effects as physical participation. And yet, initially, in the era of dynamic radio development, the popes responded negatively to questions about the possibility of transmitting the Eucharist. They were undoubtedly guided by respect for the liturgy and care for the respect for it. They believed that it was not appropriate for the celebration of the sacraments to be adjacent on the ether waves with obscene and indecent content. However, the victorious approach was the pragmatic and reasonable one, which made us ask the question whether this intransigence will cause spiritual benefit to the faithful or spiritual harm to the sick, the servants, those who are too far away from the temple, or everyone else who, for important reasons, cannot take part in the Sunday Eucharist personally? (Szczepaniak 2012, 1113). Nevertheless, the Church's stance towards the broadly defined means of mass communication has not always been favorable. The beginnings were difficult and often characterized by scepticism and mistrust, even hostility. This was not only true for radio, cinema or television, but above all for print and press. 
This article addresses these issues. The direct subject of research and analysis will be the three statements of the popes on the publications which are considered to be prototypes of modern press. These statements are the two apostolic constitutions of Pius V "Romani Pontificis providentia" and Gregory XIII "Ea est rerum" (both published in 1572), as well as Sixtus V "Bando contra li calunniatori e detrattori della fama et honor d'altri" of 11 November 1586. (this was, however, already a much smaller document). The content of these acts will be shown in a historical, social and religious context, and then analysed in terms of the message, the effects and further evolution of the Church's attitude towards the means of communication. In particular, the aim of the article is to answer the following questions: Can these papal documents be considered as the first statements of the Catholic Church on the press? What were the conditions for this particular position of the Holy See and not the other? The authors would also like to refer the content of these documents to the events of the ninth century, to the work of Constantine and Methodius, so the next research question is: Is not such a rigorous and reluctant attitude of the Church, so strict and reluctant to the modern forms of mass communication formed in the sixteenth century, a step backwards and a denial of the courageous missionary attitude of the Solon Brothers? Contrary to appearances, the answer to these questions is not simple or unambiguous. The authors of this article put forward a hypothesis that the sixteenth-century criticism of avvisi found its source primarily in an immediate political need, while arguments of theological nature had less influence on that attitude.

These issues can be attributed to the research area of media and communication theology, which is one of the subdisciplinary scientific subdisciplinary of communication and media studies. Due to the interdisciplinarity of the article and the subject of the research, the authors will use methods typical of both the social communication and media sciences, historical sciences and theological sciences (historical, linguistic and sub ratione Dei method) ${ }^{1}$. The authors will make a desktop research of available studies on the history of the press and journalism (especially on avvisi and their role in shaping the modern circulation of information in Europe) and the history of the Church, taking into account her internal situation in the sixteenth century. This will allow for a better understanding of the factors that influenced the formation of the current doctrine of the Catholic Church on the media.

The historical method is "the mapping in man of salvation events and the whole history of salvation, accomplished in biblical times and continuing cognitively throughout history. It emphasizes the empirical dimension, that is, certain historical events, studied with the means belonging to the historical sciences. In turn the linguistic method includes the study of language. Three approaches are possible: neopositivist - it focuses on syntactics; hermeneutic - it examines the meanings of Christian language and structuralist - it treats the linguistic layer as a representation of the structure of the Christian phenomenon (Remisiewicz 2015, 129). As for the sub ratione Dei method, according to H. Seweryniak (2010, 19-20) it consists of two stages. The first one „recognizes” the studied problem, taking into account its complexity, interdisciplinarity of the problem, possible conditions, etc. In the second, the theological interpretation of the problem is made, considering it in the light of biblical anthropology and axiology and the Magisterium of the Church. The points of contact between theological concepts and those taken from other sciences are also examined. In other words, we come from non-theological sites to show their theological significance (including how they broaden our culture of faith), to show coherence or inconsistency with the Catholic value system. In the case of the documents in question, the authors will attempt to read them in their proper historical context - so that, through the prism of the epoch in which they were created, the Church's efforts to achieve man's main goal, which for the Church is salvation, can be read. 


\section{State of Art}

The relationship of the Roman Catholic Church to the social media has been the subject of many studies, carried out from various research perspectives, with particular emphasis on historical, theological and social. As far as the historical perspective is concerned, it is important to note the differences in showing the beginnings of the Church's reference to the media. Jan Chrapek (1989, 245) stresses that "the Church has modified her approach to the press, film, radio and television over the course of time, in line with the changes taking place in this respect in intellectual circles. Today, the moral and defensive attitude has been replaced by an open attitude of the Church towards the means of social communication". This author distinguishes several periods in the Church's official approach to the media: the moral-defensive period (1832 - 1922), the period of the Church's openness to new media (until the Second Vatican Council), a period of in-depth theological reflection (during the Second Vatican Council) and finally the post-conciliar period (after 1965) (Scratch 1989, 231-240). Different researchers, however, take a different approach to which of the Church's official statements should be regarded as the first with regard to the social media. Much depends on the definition and understanding of the media. If we consider books as such, all papal documents on preventive censorship of prints, the index of forbidden books and everything connected with publishing books are included in this approach (Pokorna-Ignatowicz 2002, 16; Rolfes 2007, 8-9; Mordarski 2007, 35-37; Łęcicki 2012, 26-27; Adamski - Łęcicki 2019, 24). However, for many researchers, the Church's official reference to the media starts with the encyclical "Mirari vos" by Gregory XVI of 1832 (Scratch 1989, 231; Schmolke 1981, 410-412; Lewek 2003, 47) and even the pontificate of Pius XII (Kappeler 2006, 59; Caccamo 2008). This is due to the lack of recognition of the ephemeral writings already existing in the 16th century as social media. In fact, the Church has already spoken about the press and journalism in 1572 in two apostolic constitutions ${ }^{2}$. These were critical statements and kept in a forbidden tone, and in 1621 something happened that could be called an unwilling acceptance of journalistic activity.

\section{Historical and social background}

The 16th century was the beginning of the development of various forms of information distribution, considered to be the prototypes or even ancestors of modern press. These were ephemeral letters, usually written by hand. It is likely that they emerged and evolved as an offshoot of mercantile information (Infelise 2010, 51). They were called differently in different countries (gazette, avisso, mercury) ${ }^{3}$. Typical avvisos were handwritten, published before the popularisation

2 While the former, published by Pius V, is noted by some studies (e.g. Pokorna-Ignatowicz 2002,17; Świgoń 2009), the latter, published by Gregory XIII, is rather noticed only in very detailed and specialized historical studies and almost completely unknown by researchers dealing with the theology of media and communication.

3 M. Infelise explains: "In Italian the most usual term between the fifteenth and sixteenth centuries was the generic avviso (notice), which did not however distinguish between the object and its content. A German avviso could be at one and the same time a news-sheet carrying various nuove (news) coming from Germany or, more simply, a single piece of news from Germany. In Venice the term reporto was widely used with the same meaning, which was then carried to England as the word report. Consequently reportista (reporter) was synonymous with a compiler of newsletters or gazettes. In Rome from the midsixteenth to the end of the seventeenth century, the expression menante enjoyed great favor to denote a writer of handwritten work. Around 1560 the word gazzetta began to be recorded but seemed for many decades to be primarily a term belonging to the spoken language to refer to those news-sheets without any great credibility which might circulate in the city" (Infelise 2010, 53-54). In the following article the 
of a printed magazine (although also for some time after the invention of printing). Private letters were their prototype, as the role of written communication gradually grew. Monarchs and statesmen, as well as scientists and merchants increasingly used the written word to maintain mutual relations. The content was official and the language used was usually Latin, but more and more often small announcements of a general nature written in the national language were added at the end of the letter; they were read in the private circle of friends after the letter was delivered. Gradually this final message became longer and more important than the letter itself. It was copied on separate pages and then sold to interested recipients (Vanthoor 1950, 8-11).

As a separate textual genre, avvisi has existed since the 1640s. They could be purchased by subscription, and their advantages consisted in the regularity and speed of their information, mainly concerning political and military events (Nuovo 2011, 196). Avvisi more than any other source give a lively and relatively complete picture of the political and social life, customs and passions of the time. They make it easier for us to understand how political events influenced each other and how international and local public opinion was created (Van Houtte 1925, 360). Topics other than politics and military issues have been hosted by avvisi quite rarely: in Rome, religious events were occasionally discussed, and (rarely) extraordinary phenomena (fires, floods, earthquakes) were described (Petitjean 2010, 112). Roman Avvisi also included a compilation of news from the papal court and Rome, which circulated among merchants, bankers and diplomats. The information contained there concerned celebrations, performances, births and deaths, as well as events and scandals. Later, the avvisi printed in Rome and other Italian cities contained information about events from distant places (Jones - Wisch - Ditchfield 2019, 556-557).

As the content of the news was in the local language, the name of the newspaper was also changed in the local language. Avviso appeared in two variations: secreto, handwritten only, containing confidential information addressed to persons in power, and avvisi pubblici, which could be written or printed (Arblaster et al. 2016, 66-67). In Italy, Venice is considered to be their homeland, where they initially served as an official information service for ambassadors and ordinary people. However, agencies were soon set up by professional writers (scriptori d'avisi). In Rome, they were better known as novellanti or gazettanti (Vanthoor 1950, 8-11) or menanti (the origin of this word is not clear; most often it is assumed to come from Italian words meaning conduct or intrigue (Petitjean 2010, 113). In fact, Venice and Rome are rightly considered the two main centres of avvisi production in Italy (Nuovo 2011, 196). It would, however, be a mistake to say that the range of avvisi was limited to Italy only; they were known in many European countries, and among the main centres, where this - very modern for those times - form of communicating news was very popular, one mentions Vienna, Brussels, Antwerp and Prague among others (Petitjean 2010, 111-112).

There is a difference of opinion among historians as to whether, due to its form and content, avvisi can be called the ancestor of modern press. This is how most historians perceive them (Petitjean 2010, 116), although M. Infelise $(2004,212)$ stipulates that avvisi have a slightly different genesis than the modern press - namely, that they are a child of Italian love for political intrigue and debate. J. Raymond (2008, 1-2) notes, on the other hand, that in order to speak of a newspaper as it is understood today, six characteristics must be met: publication, i.e. commercial accessibility for the public, regular periodicity, serial publication, continuity of the title and physical format, timeliness of the content and heterogeneity of the content. Nevertheless, it acknowledges that: "manuscript news media [...] constituted an early modern media revolution that was central to state formation, reading, and politics in this period. The quantity of news provision increased,

authors are going to use the Italian term „avvisi“. For more concerning the naming and origin of the various terms see: (Arblaster et al. 2016, 66-67; Petitjean 2010). 
resulting in a qualitative transformation, and news media became embedded in politics and culture" (Raymond 2008, 1).

It should be noted that although externally avvisi resembled ordinary letters, they were the product of conscious activity of the correspondent, who treated their editing and distribution in a professional manner, making them a source of income. These letters had a permanent title, and lacked the typical courtesy and interest in the personal affairs of the addressee (Wolert 2005, 52). Thus, they could definitely be considered the prototype of the modern press, although the printed press did not appear until the next century.

\section{Research}

The Apostolic Constitution occupies a very high position in the hierarchy of importance of official Church statements. It is the Pope's solemn letter of faith or ecclesiastical discipline, which applies to all or part of the Church [...]. By virtue of the Constitution the truths of the faith (e.g. dogmas), norms concerning liturgy and ecclesiastical discipline are proclaimed (Catholic Encyclopedia 2002, 732). The promulgation of a document of this rank therefore means that the two popes mentioned above attached great importance to the issues discussed in them.

Both constitutions were published in 1572, only 6 months apart. The first was issued by Pope Pius V (1566 - 1572), a few months before his death ${ }^{4}$.

It was entitled "Romani Pontificis providentia" and was published on 17 March 1572. In the 'Romanum Bullarium' it is explained that it was written 'Contra scribentes, dictantes, retinentes, transmittentes et non lacerantes libellos famosos atque litteras nuncupatas d'avvisi, continentes alicuius famae laesionem futurorumque successuum et corum que pro regimine Status Ecclesiastici secreto tractantur revelationem. (Bullarium Romanum 1862, 969-971). (Against writers who write, dictate, preserve, transmit, and do not destroy defamatory books and writings called d'avvisi, containing a violation of someone's good reputation, and the disclosure of future events and things that are treated in secret for the management of the Church).

This short text consists of two parts. The first part contains a reference to the situation that caused the Pope to decide to issue this letter. At the outset, it refers to the already existing regulations relating to the publication of "defamatory books". (famosum libellum). The Pope reminds us of the total ban on publishing them, and of the rules for dealing with them, if someone finds or otherwise comes into possession of such a book ("and if someone finds such a book, whether at home, in a public place or any other place, he is obliged to destroy it or burn it before someone else finds it, and not to reveal to anyone what he has found, but whoever does otherwise will be subject to the same penalties as the author of such a crime"). Further, the Pope regrets that severe punishments do not deter the authors of these publications. They are called "sons of

4 As Pope Pius V, he acted in three directions: the introduction of the Trentine reform into the life of the Church, the fight against numerous heresies of that time and the fight against Islam (Kumor 2004, 172). He was characterized by a modest lifestyle and extraordinary piety. Faced with great diversity in the field of liturgy, he tried to unify the liturgical books. Thus he gave rise to „curial centralism“. (Tüchle - Bouman 1986, 132). During the pontificate of Pius V, the „Roman Catechism“ (a textbook for the preaching and catechetical activities of the clergy), the "Roman Breviary“, the „Roman Missal“, among others, were created, and work began on the final determination of the text of the Vulgate. He took up the fight against heresies with great determination. In 1568, he published the „Bull“ on Thursday, in which he collected "church censorship against the heresies of the time“. (Kumor 2004, 172). Some authors note that the pontificate of this pope gave the church a "spirit of certainty and authoritarianism“. (W. J. La Due, 251), which was due to fear of the spread of heresy. 
injustice and disciples of loss" (iniquitatis filii, perditionis alumni), and in the long catalogue of the titles of their wines it is mentioned "touching with various insults and insults some rulers, prelates, noblemen, public and private persons, taking away their good fame and honor" and telling not only what happened, but "also what - according to the bold judgment of the authors - will happen in the future". This catalogue of guilt is extended in the second part of the Constitution to include making, dictating, writing, copying, preserving or transmitting to anyone "libelous books and writings called in spoken language lettere d'avvisi, containing insults, insults, and violations of someone's good name and honor, or any writing that deals with future incidents, or reveals what is secretly treated before us or before other persons appointed to administer the state of the universal Church".

The result, according to the Pope, is "hatred, hostility, rioting, quarrels, murders, an insult to God's majesty, a danger to souls, and a disastrous example and a disgrace to many. And all this is done "under the imaginary pretense of some writing, by an unknown author, not only from our city [i.e. Rome], but from various provinces. The Constitution imposes sanctions on publishers, distributors or owners of such writings, putting them on an equal footing. Although the document does not explicitly mention the penalties that threatened to be imposed for these crimes, it is known that they were very drastic, including the death penalty ${ }^{5}$.

The second constitution, known as "Ea est rerum" (Bullarium Romanum 1863, 12-13), was issued on September 11, 1572 by Gregory XIII, considered to be one of the most outstanding popes ${ }^{6}$. The document is headlined: "Contra famigeratores nuncupatos "menantes" corumque scripta recipientes et famosos libellos scribentes et mittentes" (Against gossipers, known as "menanti" [Italian designation for editors of the aforementioned lettere d'avvisi], and those who receive their writings, and against those who write and send out defamatory books.) The structure of this document is similar to the previous one. In the first part, however, the extensive (albeit negative) characteristics of the people who publish the "lettere d'avvisi" are noted. They are even called "a sect of indecently curious people" (setta hominum improbe curiosorum)," who can either find out everything about public and private matters, which they can either find out from everywhere, or make up their own mind as they like, [...] whether it happened or not, whether it was true or false, they report, accept, write down, in such a way that they have already created some new art of it". Then many of them write "usually collected from false gossip of the crowd, of unknown authorship, here and there, they send out." In these notes, "not only do they mock past things as they please, but also what is to come out of this or that thing, they ridiculously prophesy. For making such notes or accepting, transcribing and distributing them, there was a risk of being sentenced to galleys (for life or time). The justification for such drastic steps is the "great evil" that results from the distribution of these writings - "because false things instead of true things are often spread, either directly or indirectly, and by some artificial pretence good fame and opinion is violated by others."

Such a severe punishment was given to a certain Annibale Cappello, among others, although there are voices saying that he was not a typical Roman menante and that he was convicted primarily of serving heretics and writing pornographic books (Lee 1991, 90).

6 Gregory XIII (1572 - 1585) was the successor of Pius V and continued the church reform. He was a professor, an expert in law, and was committed to supporting science (e. g., he significantly contributed to the development of Collegium Romanum). He believed that a good clergy education was extremely important for the church. He led the reform of the Julian calendar, creating the Gregorian calendar (named after this Pope). He also reformed church music. Like his predecessor, Pius V, he implemented reforms of the Council of Trent. He made special efforts in the struggle against the spread of Calvinism in northern European countries. (Tüchle - Bouman 1986, 132-136; Kumor 2004, 171-174). 
The letter issued by Sixtus $V^{7}$ on 11 November 1586 was entitled: 'Bando contra li calunniatori e detrattori della fama et honor d'altri's ('banishment against slanderers and detractors of fame and honor of others'). However, it was a document of a much lower rank than the Apostolic Constitution, a letter of a typically administrative nature. It concerned the same behaviour as the two above-mentioned letters. It also sustained severe punishments for the above acts: death sentence, confiscation of property and eternal shame ("condanna a morte, confisca dei beni ed infamia perpetua") (Lee 1991, 90).

The rigour and severity of the documents in question may be astonishing today. For the people of the 21 st century, brought up in the spirit of interreligious dialogue, ecumenism and tolerance, such a drastic restriction of freedom of speech is unacceptable. However, we must remember that the interpretation of views, legal acts or behaviours must take into account the context of the era in which they took place. Therefore, the interpretation of the Pope's teaching on the media requires us to take a broader view.

Above all, it is important to remember the very important assumption for the Church that the highest good of man is the salvation of his soul'; it takes precedence over such values as freedom or even life. Meanwhile, the fourteenth and fifteenth centuries were full of new philosophical ideas and religious and political events (including the crisis of papal authority, Western schism, ideas proclaiming the sovereignty of the people and of every ruler, the separation between politics and morality, and especially the beginning of the Reformation). The first Protestants intensively disseminated their ideas by printing in large quantities (books, brochures, letters), using the local language (and not like the Latin elite of the time). The spread of printing allowed for a kind of "media war" between Protestantism and Catholicism - already in 1534 French Protestants used the press to publish their ideas. In Switzerland, on the other hand, posters ridiculing Catholic rituals were hung, in other countries, satirical poems and caricatures were spread on house walls and brochures were distributed (Briggs - Burke 2010, 102).

The Popes of the Reformation era were strongly focused on politics, and the Church itself was increasingly in crisis, both on the spiritual, internal and organizational levels. It was only in the first half of the 16th century that the papacy gradually changed on the religious and moral level. A radical reform leading to an end to the crisis was brought about by the Council of Trent, called by Pope Paul III in 1544 with the bull "Laetare Jerusalem"10, and its opening took place on 13 December 1545. It lasted for three separate periods: in the years 1545 - 1547 for the pontificate

7 Sixtus V (1585 - 1590), was the successor of Gregory III and, despite a rather short pontificate, introduced many changes in the structure of the church's supreme authority, which remained valid for several centuries. He also arranged the issues of dealing with the affairs of the universal Church and the Church State. He was the founder of 15 cardinal congregations for more important matters, whose activities and structures were precisely defined. He was the founder of the Vatican Printing House mainly in order to prepare a new edition of the Vulgate. (Banashak 1989, 133; Tüchle - Bouman 1986, 136-138).

8 The scan is available online in a digital version: http://dr.casanatense.it/drviewng.html\#action=jumpin;id bib $=1299$;idpiece $=-1$; imageNumber $=1$.

9 It is based on a passage from the Gospel that says: „Well, if your hand or your leg is the cause of sin for you, cut it off and throw it away! It is better for you to enter into life with a crippled or chilly person than with two arms or two legs to be thrown into eternal fire. And if your eye is the cause of sin for you, cut it out and throw it away! It is better for you to come into life with one eye than with two eyes to be thrown into a fire hell. (Mt 18, 8-9; cf. Mk 9, 43-48).

10 The first councils were convened by the emperors, so they were presidents. It was not until the Fourth Lateran Council (1215) that these duties were taken over by the Pope, who could attend the Council in person or delegate his Legates (which took place, among other things, during the Council of Trent). (Sitkowska 2013, 9-10). 
of Pope Paul III, then in the years 1551 - 1552 for the pontificate of Pope Julius III and in the years 1562 - 1563 for Pope Pius IV. (Kumor 2004, 162). The three successors of Pius IV, who ended the Council of Trent, were called the Great Trent Popes (Pius V, Gregory XIII and Sixtus V). (Banashak 1989, 123). They are the authors of the documents discussed in this article.

The tool of counter-reformation was, among other things, the development of an index of forbidden books, which the faithful were not allowed to read. Moreover, they could not be traded, they could not even be kept, and their finder was obliged to deliver them to the Inquisition. However, it turned out that there was a gap in this fearful flow of uncontrolled information and opinions of regulations. There was no mention of handwritten private letters... However, they often revealed information that the popes would prefer to keep secret. As already mentioned, their authors did not avoid repeating rumours or spreading untruth on purpose. The Pope's response to this problem was very strict legal regulations. Their enforcement was all the easier because the popes of that time had not only spiritual power, but also the secular, including military power, according to the current doctrine of Caesarpapism. It must be remembered, however, that its doctrinal assumptions "were not of a dogmatic nature, but were the result of an extreme interpretation of Christian dualism, which arose in a specific historical situation". (Krukowski 1993, 27).

Similarly, criticism of the authors of avvisi cannot be seen as a dogmatic statement, but above all as an administrative one. Today, it could be compared to the struggle with fake news that "are analysed as a 21 st century biggest thread of new media". (Pasławska - Popielska-Borys 2018, 136) ${ }^{11}$. The Pope's worries concerned primarily the dissemination of bad or confidential information, e.g. about the Pope's health, about clergy or information of a sensational nature. The Pope's health in particular was a taboo subject. The Romans waited impatiently for the time sede vacante, i.e. the period between the Pope's death and the election of his successor. At that time, the papal law ceased to apply. If the Pope was infamous and disliked, the people attacked his statue on Capitol Hill. It can be seen that the disinformation about the expected death of the Pope was seen as a threat to order and also undermined the authority of the papal authority, causing confusion and chaos in the streets of Rome (Hunt 2014, 145-146).

Therefore, in the Pope's reaction, there is no point in looking for direct theologicalphilosophical motivations. He acted in the same way as many rulers at that time - he reacted to the uncontrolled spread of information (especially false information) which could have damaged his authority or put his power at risk. ${ }^{12}$ Already in 1275 England issued a decree against the spread of false messages. Similar measures were taken by Charles V (1519 - 1556) and Philip II (1556 1598) (Vanthoor 1950, 16), among others.

On the other hand, there was a growing realisation that the flow of reliable information was necessary, at least for the mighty of this world. In 1572, the Venetian decree exempted ambassadors, secretaries and representatives of the princes from the ban on avvisi, thus recognising that their

11 On the other hand, it is puzzling and worrying that after so many centuries of media development, in the era of ethical and legal regulations concerning journalism, one of the main challenges for the media is to fight for the truth, which in the era of disinformation, fake news, propaganda and the collapse of journalistic ethics becomes a scarce commodity (Los 2015, 33). However, the process of reaching the truth is complex and different for every human being; it takes place „inside the human soul and through the senses, imagination, experience and intellect in various ways". (Ntotsika 2019, 39). The task of the Church is to accompany people on this journey, the task of the media is to help to reach the truth, or at least not to interfere with it.

12 What is worrying in the history of the Church, however, is the fact that often, despite emphasizing the importance of morality and fidelity to the Gospel, the actions of the popes were primarily aimed at the maintenance of military, political, economic and social power (Cf. Gluchman 2017, 62). 
production and dissemination was essential for the smooth running of politics (Infelise 2002, 156157). The secular authorities changed their policy towards publishers quite quickly and granted those who wanted to submit to censorship a patent or permission to print certain documents (Vanthoor 1950, 16). The situation was somewhat different in Rome: since 1602, any dissemination of the avvisi required the written consent of the City Governor. They began to be considered a dangerous category of writings, and their circulation was prohibited regardless of their content. They were subject to similar censorship to printed magazines (Infelise 2002, 155; Dooley 1999, 1326). However, the repression did not yield great results, mainly because the custom of reading avvisi has gained great popularity. Moreover, only some content was unacceptable. Thus, if there were no violations against the Pope and his rights in his writings, no sanctions were imposed. D'Onofrio (1962) points out that it issued on 6 March 1621. The "Bando generale concernente il Governo di Roma" distinguishes between "menanti" and "libellisti" in Chapters 28 and 29, that is to say, between dissemination activities (avvisi) and the production of slander and misinformation. The first category of activity was subject to censorship and the obligation to obtain a licence, while the second was still subject to severe penalties, including the death penalty. In his opinion, this could be a sign of reluctance, but still a recognition by the Church of a certain professional group that deals with the dissemination of news. He considers this act to be a kind of edict tolerant of the then precursors of journalism (D’Onofrio 1962, 541).

\section{Discussion and Conclusions}

The media doctrine of the Church has long been characterised by mistrust. It was also visible in following centuries, especially in the 19th century. This was due to many factors, for example, the fact that the press (already in its modern version) was often used by enemies of the Church. On the other hand, the pope's desire to control the transmission of information and thoughts is still visible. Even when they called (beginning with the Encyclical Nostris et nobiscum given by Pius IX in 1849) for the creation of a "good press", this would still be done under the control of the Church. But the Church quickly realized that the progress of the media is inevitable and instead of being offended by this new reality, the media should be used as a tool for preaching the Gospel and for communicating one's own teaching and point of view to the world. The creation of the daily L'Osservatore Romano (1861) or Vatican Radio (1931) is certainly an important result of this reflection.

On the other hand, St. Francis of Sales, recognized as the patron saint of journalists, already in the 16th century did something that today could be described as evangelization through the media. A similarly bold (even pioneering) attitude was presented much earlier by the 9 th century Saints Constantine and Methodius. At first, it seems that they have nothing to do with the situation and moment in the history of the Church described in the article. Nothing could be further from the truth! The key to understanding are the words of P. Soukupa $(2019,26)$ : "The history of Christianity could be written as a history of communication, with media playing a role both in faith development and in evangelization. Although Constantine and Methodius did not use social media, in preaching the Gospel they referred to another medium (or rather meta-medium), which is language. A language which (following Gadamer's thought) is a universal area in which human reason and cognition are realized, not just a collection of formal signs (Bronk 1988, 301-303). A language "is created by man, but at the same time shapes its own creator. It develops together with man. Language is an integral part of man's ontological heritage, a testimony of his bodily and spiritual structure. Language appears as a hermeneutic; as a reading of the essence of being and a description of its broadest horizon". (Liszka 2005, 340-341). Thus, the action of Constantine and 
Methodius was more than just a simple act of translation. They considered the language of the Slavs to be "an effective tool for bringing the truths of God closer to us" (SA, 12). In order to do so, they themselves had to know the "language and mentality" of these peoples (SA, 11), to immerse themselves in it. In this way they were able to transmit the Gospel message "in conformity with eternal truths and at the same time adapted to the concrete historical situation". (SA, 21). The key word here is "inculturation". The culturally creative effects of their activities on the culture of Slavic peoples are enduring. Thus, theirs was not an attitude of fear, separation, and escape, but an attitude of a courageous mission with the message to bring the Gospel to the world and thus to transform it. Already in the ninth century, they had understood perfectly what Benedict XVI articulated in the 21st century: "the world of communications involves the entire cultural, social and spiritual universe of the human person. If the new languages have an impact on the way of thinking and living, this in some way also concerns the world of faith and the understanding and expression of it". (Benedict XVI 2011).

One may ask, then, what made the Church adopt such a defensive and conservative attitude towards new communication techniques several hundred years later? The crisis and the expansion of Protestantism in print are explanations that are suggested, but they are too simple and convenient. Did Constantine and Methodius work in a less complex world? Yes, they were invited to Rome by the Pope (Pope Nicholas I (858 - 867) and met Pope Hadrian II (867 - 872) and John VIII $(872$ - 882)) (Husár 2016, 37). But from the very beginning of their missionary activity, they encountered opposition and resistance from the supporters of the so-called Pilate's pseudo-theory. Advocates of the theory proclaimed that God chose only Hebrew, Greek and Latin as the languages of worship, and denied the right to use the Slavic language to celebrate liturgy and to translate the Scripture into it (Bartula 2012, 13). John Paul II explains the reasons for this resistance in the following way: "Western Christianity, after a period of peoples' wandering, melted the arriving ethnic groups with the local Latin population, spreading the Latin language, liturgy and culture transmitted by the Church of Rome to all in order to unify the Latin language, liturgy and culture. Such uniformity awakened a sense of strength and compactness in relatively young societies, and had an impact on their development, all of which helped to strengthen their unity and position in Europe. It can be understood that in this situation any difference was felt as a threat to that unity in fieri, and there was a great an attempt to remove it by means of various forms of coercion ". (SA 12).

As you can see, the situation of the Church after the Council of Trent did not differ from the realities in which Constantine and Methodius worked. What, then, made the Church choose the path of "breaking up the chicas" in the 16th and 17th centuries? Why didn't the brilliant intuition of St. Francis of Sales, who instead of censoring the Protestant scriptures, took up the challenge and filled the space of the printed word with the language of the Gospel and the teaching of the Church, find followers? Why did the spirit of censorship, control, and entrenchment prevail in the Church for the next few hundred years?

It is impossible to give a complete answer to these questions in one article. We just want to point out that contemporary changes in communication technology also have an impact on culture, because they change the environment in which people live, their mentality, their ways of thinking, sensitivity, the organisation of work and leisure time... Marshall McLuhan and Walter J. Ong even claimed that the Reformation was the result of the emergence of printing in Europe the dissemination of this technique of copying thoughts created, in their opinion, a new reality for which the Church was not properly prepared (Chrapek 1990, 12-18). It took the Church a long time to understand that the world of media and communication was above all a challenge to be met. Instead of running away from it, one has to meet it with courage and trust, as Constantine and Methodius did. 
The Church's Attitude to the Means and Philosophy of Communication in the 9Th and 16Th Centuries: Courage and Trust Versus Escape and Censorship

\section{REFERENCES}

Adamski, Andrzej - Łęcicki, Grzegorz. 2019. Inter mirifica - a still relevant document. In European Journal of Science and Theology 16/4, 23-32.

Arblaster, Paul et al. 2016. The Lexicons of Early Modern News. In Pettegree, Andrew (ed.). News Networks in Early Modern Europe. Leiden - Boston, 64-101.

Banaszak, Marian. 1989. Historia kościoła katolickiego, cz.3: Czasy nowożytne 1517-1758. Warszawa.

Bartula, Czesław. 2012. Ze studiów nad Żywotami Konstantyna i Metodego. In Slawistyka 12, 11-14.

Benedict XVI. 2011. Address of His Holiness Benedict XVI to participants in the Plenary Assembly of the Pontifical Council for Social Communications. http://www.vatican.va/content/benedictxvi/en/speeches/2011/february/documents/hf_ben-xvi_spe_20110228_pccs.html

BR. 1862. Bullarium Romanum, VII, 969-971. Torino.

BR. 1863. Bullarium Romanum, VIII, 12-13. Torino.

Briggs, Asa - Burke, Peter. 2010. Społeczna historia mediów. Od Gutenberga do Internetu, transl. by Jakub Jedliński. Warszawa.

Bronk, Andrzej. 1988. Rozumienie, dzieje, język. Filozoficzna hermeneutyka H.-G. Gadamera. Lublin.

Chrapek, Jan. 1989. Kościół wobec środków społecznego komunikowania. In Ethos 31/8, 230-245. Chrapek, Jan. 1990. Współczesne techniki komunikowania nowym wyzwaniem dla Kościoła. In Chrapek, Jan (ed.). Kościół a środki społecznego przekazu. Warszawa, 11-19.

D’Onofrio, Cesare. 1962. Gli «avvisi» in Roma dal 1554 al 1605. In Studi Romani, 10/5, 529-548.

Dooley, Brendan. 1999. De bonne main : les pourvoyeurs de nouvelles a Rome au XVIIe siecle. In Annales. Histoire, Sciences Sociales. 54/6, 1317-1344.

EK. 2002. Encyklopedia katolicka. t. IX, KUL, Lublin.

Gluchman, Vasyl. 2017. Krestanstvo a morálka v stredoeurópskej politike 9. storočia [Christianity and Morality in Central European Politics of the 9th century]. In Konštantínove listy [Constantine's Letters] 10/2, 62-74.

Hunt, John. 2014. Rumour, Newsletters, and the Pope's Death in Early Modern Rome. In Davies, Simon - Fletcher, Puck (eds.). News in Early Modern Europe. Currents and Connections. Leiden - Boston, 141-158.

Husár, Martin. 2016. Vybrané aspekty ceremónií a audiencií spojených s pobytom Konštantína a Metoda v Ríme. Otázky procesií a architektúry [Selected Aspects of Ceremonies and Audiences Regarding Constantine and Methodius' Stay in Rome. A Question of Processions and Architecture]. In Konštantínove listy [Constantine's Letters] 9/1, 29-38.

Infelise, Mario. 2002. Prima dei giornali. Alle origini della pubblica informazione. Roma-Bari.

Infelise, Mario. 2004. Roman avvisi : information and politics in the seventeenth century. In

Signorotto, Gianvittorio - Visceglia, Maria Antonietta. Court and Politics in Papal Rome 1492 - 1700, 212-228. Cambridge.

Infelise, Mario. 2010. News Networks between Italy and Europe. In Dolley, Brendan (ed.). The Dissemination of News and the Emergence of Contemporaneity in Early Modern Europe. Farnham - Burlington, 51-68.

Jones, Pamela - Wisch, Barbara - Ditchfield, Simon. 2019. A companion to Early Modern Rome 1492 - 1692. Leiden - Boston.

Kappeler, Warren. 2006. Communication Habits on the Pilgrim Church: Vatican Teaching on Media and Social Communication. Montreal.

Krukowski, Józef. 2000. Kościół i państwo. Podstawy relacji prawnych. Lublin. 
Kumor, Bolesław. 2004. Historia Kościoła, Czasy nowożytne. Rozłam w chrześcijaństwie zachodnim, cz. V. Lublin.

La Due, William J. 2004. Na tronie świętego Piotra. Historia Papiestwa. Wrocław.

Liszka, Piotr. 2005. Język jako instrument i przedmiot teologii. In Rosik, Mariusz (ed.) Żyjemy dla Pana: księga pamiątkowa dedykowana S. Profesor Ewie Józefie Jezierskiej OSU w siedemdziesiątą rocznicę urodzin. Wrocław, 339-369.

Los, Josyp. 2015. The word that enslaves or the word that liberates? In Social Communication Online Journal 1/11, 28-34.

Łęcicki, Grzegorz. 2012. Media audiowizualne w nauczaniu Jana Pawła II. Warszawa.

Lee, Valeria Sestieri. 1991. Avvisi a stampa e manoscritti nella Roma del '500. In QUADERNI d'italianistica XII/1,83-92.

Lewek, Antoni. 2003. Podstawy edukacji medialnej i dziennikarskiej. Warszawa.

Mordarski, Stefan. 2007. Media w działaniu. Funkcjonowanie środków społecznego przekazu w świetle nauczania Kościoła. Sandomierz - Kraków.

Murvar, Vatro. 1967. Max Weber's Concept of Hierocracy: A Study in the Typology of ChurchState Relationships. In Sociological Analysis, 28/2/69, 69-84.

Nuovo, Angela. 2011. Manuscript Writings on Politics and Current Affairs in the Collection of Gian Vincenzo Pinelli (1535-1601). In Italian Studies 66/2, 193-205.

Ntotsika, Alexantra. 2017. The Truth in Aristotle and Sophonias. In Konštantínove listy [Constantine's Letters] 1/10, 36-42.

Petitjean, Johann. 2010. Mots et pratiques de l'information. Ce que aviser veut dire (xvie-xviie siecles). In Mélanges 122/1, 107-121.

Pokorna-Ignatowicz, Katarzyna. 2002. Kościół w świecie mediów. Historia-dokumenty-dylematy. Kraków.

Pasławska, Paulina - Popielska-Borys, Anna. 2018. Phenomenon of fake news. In Social Communication Online Journal (special issue 2018), 136-140.

Raymond, Joad. (2008). Newspaper, Antecedents of. In Donsbach, Wolfgang (ed.). The International Encyclopedia of Communication. Wiley, 1-5.

Remisiewicz, Łukasz. 2015. Teologia jako nauka formalna. In Analiza i Egzystencja 32, 113-142.

Rogala, Krzysztof. 2018. Kształtowanie się relacji między państwem a Kościołem. Aspekt historyczno-prawny. In Teologia i Człowiek 41/1, 67-83.

Rolfes, Helmuth. 2007. Inter mirifica and What Followed: The Second Vatican Council and the Beginning of a New Era in the Relationship between the Church and the Media. In Rolfes, Helmuth - Zukowski, Angela Ann (eds.). Challenge of Theology and Ministry in the Church; Festschrift for Franz-Josef Eilers. Kassel, 8-27.

SA - Jan Paweł II. 1985. Encyklika "Slavorum Apostoli". Vatican.

Schmolke, Michael. 1981. Information and the Mass Media. In Adriányi, Gabriel - Jedin, Hubert Dolan, John. History of the Church, vol. 10: The Church in the Modern Age. Crossroad, 410-435.

Seweryniak, Henryk. 2010. Teologie na "progu domu”, In Kultura - Media - Teologia, 1/1, 10-23. Sitkowska, Katarzyna. 2013. Aspekty organizacyjne i komunikacyjne II Soboru Watykańskiego. In Kultura-Media-Teologia 1/12, 8-21.

Soukup, Paul A. 2019. Some past meetings of communication, theology, and media theology. In Kultura-Media-Teologia 3/38, 25-46.

Szczepaniak, Maciej. 2012. Radiowa transmisja mszy św. z Kongresu Eucharystycznego w Dublinie. Przełom w recepcji transmisji radiowych w praktyce eklezjalnej. In Kultura-Media-Teologia 2/9, 8-19. 
Świgoń, Michał. 2009. Stosunek Kościoła do prasy na przestrzeni wieków w świetle dokumentów kościelnych (cz. I). In Histmag.org. https://histmag.org/Stosunek-Kosciola-do-prasy-naprzestrzeni-wiekow-w-swietle-dokumentow-koscielnych-cz.-I-2566?id=2566.

Tüchle, Hermann - Bouman, C. A. 1986. Historia kościoła, cz. 3, 1500-1715. Warszawa.

Wolert, Wiesław. 2005. Szkice z dziejów prasy światowej. Kraków.

Van Houtte, Hubert. 1925. Un journal manuscrit intéressant (1557-1648). — Les Avvisi du Fonds

Urbinat et d'autres Fonds de la Bibliotheque Vaticane, In Bulletin de la Commission royale d'Histoire 89, 359-440.

Vanthoor, Rene. 1950. De ontwikkeling van de Pers in Belgie. Brussel.

Prof. Andrzej Adamski, PhD.

University of Information Technology and Management in Rzeszow

College of Media and Social Communication

ul. Sucharskiego 2

35-225 Rzeszow

Poland

aadamski@wsiz.edu.pl

ORCID: 0000-0002-4075-4224

Barbara Przywara, PhD.

University of Information Technology and Management in Rzeszow

College of Media and Social Communication

ul. Sucharskiego 2

35-225 Rzeszow

Poland

bprzywara@wsiz.edu.pl

ORCID: 0000-0003-0674-1080

Sylwia Przybyło, PhD.

University of Information Technology and Management in Rzeszow

College of Media and Social Communication

ul. Sucharskiego 2

35-225 Rzeszow

Poland

ORCID: 0000-0001-7936-0444 